\title{
Influence of Ancient Indian Wisdom on R.W. Emerson's Literary Corpus
}

\section{Dr. Hafiz Mohammad Arif ${ }^{1}$, Dr. Mohammad Tariq (Tariq Faraz) $)^{1 *}$}

\author{
${ }^{1}$ Associate Professor of English and Head, Department of Languages (English), Faculty of Humanities and Social Sciences \\ Integral University, Lucknow, India \\ arifmohdhafiz@gmail.com \\ ${ }^{1}$ Assistant Professor of English, Department of Languages (English), Faculty of Humanities and Social Sciences \\ Integral University, Lucknow, India \\ lkotariqfaraz@gmail.com \\ ${ }^{1 *}$ Corresponding Author: Dr. Mohammad Tariq (Tariq Faraz)
}

\begin{abstract}
The paper exploresthe influence of Indian Ancient Philosophy and its significant strand in the American literary tradition. Why did culture, myth, history and philosophy of the East fascinate such a towering figure of the mid- $19^{\text {th }}$ century Classic American literature, R.W. Emerson. This is an attempt to analyze how he looked towards the East for creative inspiration and sustained spiritual guidance. The investigation tries to trace the instances where he holds the Middle East in great esteem and regards the intellectual feats of Oriental civilizations. The study finds that Emerson provided the American people with a new momentum of literary milieu. There was every reason for the people of America to go through the ancient literature, to study history, fictions, culture, religions and spirituality. The curiosity in having discussion about the East increased. The Eastern Studies became their prime attention. The American erudition praises the Ancient Wisdom after they had exuded in turning page after page to penetrate into the Harem of the East. What makes this study especially interesting and is worth establishing is the Cultural variations with great possibilities of cross- cultural influences as an integral part of Emerson's engagement with the Eastern philosophy.
\end{abstract}

Keywords-Orient, Brahmins, Zoroaster, Transcendentalism, Occident, Individualism and Self-Reliance.

The attempt, in this article, has been made to figure out the nature and notion of the Oriental philosophy in the writings of R. W. Emerson. It is indispensable for this academic engagement to assess the nature and extent of Eastern influences on his mind that shaped his general outlook on life. It will certainly result in exhibiting the true view of the Occident concerning the Orient. The period of Emerson had witnessed the contemporaneous interest in the Middle East. Emerson came at a time in the history of literary world, when the Orient and the Occident had started to carry conviction to each other, it was the moment when a general perception was developing that the wisdom knows not national boundaries, and it is universal in nature.

Emerson's period was the transition period when the Oriental nations were opening their doors to foreign commercial travelers and offering the heartiest welcome to them. This resulted in intercommunication and social communication between Asia and America. Emerson can be listed as one of the pioneers of American writers to venture into the literature of Asia, absorb it sufficiently, and to translate the Orient's doctrines for his American readership.

His never- ending devotion, deep esteem for Oriental philosophy and Emerson's curiosity for and interest in the sacred writings of the East most possibly began during his Harvard days which is his alma mater, and continued throughout his life. During his study time he had obtained the Hindu Sacred Scriptures as Laws of Manu, Vishnupurana, the Bhagavad-Gita, and Katha Upanishad, and years later, he made numerous references to these Scriptures in his Journals and Essays which were published in 1841 and 1843 as "Essays." Emerson, Thoreau and other Transcendentalists, who were deeply interested in the concept of 'Selfhood,' found in Hindu scriptures a well-elaborated doctrine of Self which is based on his concept of the 'Over-soul.' He found in Hindu scriptures that the central core of one's Self, (Antaraa-tma in Hindi and Khudi in Urdu) or Self - realization is identifiable with the cosmic whole (Brahma). The Upanishads reads: "The Self within you, the resplendent, 
immortal person, is the internal self of all things and is the universal Brahma."The concept similar to this cardinal doctrine of 'Vedanta' appears in the writings of the Transcendentalists. Perhaps the most appropriate commentary on their relationship with Indian literature was made by Mahatma Gandhi after reading Emerson's Essays and Journals. He acknowledges him as "The essays to my mind contain the teaching of Indian wisdom in a Western 'guru.' It is interesting to see our own sometimes differently fashioned." (Reninger Vaid. source text- Emerson:Selected Essays and poems.263). It can be observed that in majority of his poems, Emerson derived a number of themes and titles from the Hindu scriptures. For instance, "Brahma," comes from the Upanishads, and "Hamatreya," from the Vishnu Purana. Some other poems which definitely derive inspiration from the Indian Scriptures are "Wood Notes," "The CelestialLove," "Sphnix" and "Spirits," etc. "Brahma," is however, the real essence and perfect embodiment of Emerson's studies in Indian Scriptures. It would be in perfect order to quote his complete poem "Brahma" from Ralph Waldo Emerson - Poems-, to underline his curiosity and personal interest in the Hindu Scriptures:

If the red slayer thinks he slays,

Or if the slain thinks he is slain,

They know not well the subtle ways

I keep, and pass, and turn again.

Far or forgot to me is near;

Shadow and sunlight are the same;

The vanquished gods to me appear,

And one to me are shame and fame.

They reckon ill who leave me out;

When me they fly, I am the wings;

I am the doubter and the doubt,

And I the hymn the Brahmin sing.

The strong gods pine for my abode,

And pine in vain the sacred Seven,

But thou, meek lover of the good!

Find me, and turn thy back on Heaven.

Significantly, Emerson here seems to be a Brahmin who sings of Brahma, "And I the hymn the Brahmin sing." According to Emerson, Brahma is God, the essence, the reality, source of all activity and doer of all things who advises the whole humanity to come under His shelter, and search for Him through prayers. It is observable that these quoted lines owe their inspiration to Emerson's studies in Hindu Scripture. As Hindu philosophy reveals that there is a ceaseless cycle of birth and deaths and by virtue of nobility of actions and purity of hearts, the soul ultimately merges into Brahma. It says that the soul of every individual finally comes to him from the Over-Soul. This is in Hindu Philosophy 'Nirvana'; it is to be believed the highest state of the spiritual development. This is the Hindu 'Vedantic'philosophy and Transcendentalism of Emerson which shapes the framework of this well-known poem. The description of The Sacred Seven in the poem is quite significant for the scholar of Oriental Studies. According to a Hindu myth, the Sacred Seven have been linked to the 'Sapta Rishis,' the seven highest saints. They form a constellation of seven stars, called 'Sapta Rishis,' for it was the 'Seven Rishis' who were transformed into the stars. The central idea of the poem is taken from the $19^{\text {th }}$ Verse of the Gita. In the Katha Upanishad also there is a passage which is directly echoed in the theme of "Brahma." "If the slayer things that I slay; if the slain things I am slain, then both of them do not know well. (The soul) does not slay nor is it slain." The study notices that the concept of Individualism and Self- Reliance in the Oriental philosophy finds presence in the bulk of his works. In his major poems, some of them have been cited below; there is ever an effort on the part of this transcendentalist to achieve a fine blend of the West and the East. His poems, such as "Hamatreya," (a poem composed in 1845) showed that he had digested his Indian philosophic readings very well. 'Vishnu Purana,' was the source of moral truth and had an appealing massage for Emerson to create "Hamatreya." His "Hamatreya," (hail to thee, O Mother, "Hai Maitreya,"brings out the Hindu influence on Emerson. The title, theme, thought and inspiration have been derived from the 'Vishnu Purana'. This exquisite lyric finds presence in his Journal. He quoted a long passage from 'Vishnu Purana.' It guides the readers to reach the core thought of the poem. He says: "Kings who with perishable frames have possessed this ever- enduring world and who have indulged the feeling that suggests, "This earth is mine," 'it is my son's,' 'It belongs to my dynasty'- have all passed away. Earth, smiling with autumnal flowers, seems to laugh at all those who claimed to possess her, for all now possessed by her." (1845) This long poem is a celebration of the glory and majesty of Earth, mother of man. It brings out man's liability to err. Emerson seems to be an ideal moralist, exhorts mankind to give attention to the call of "Earth -Song." These lines are the part of his "Hamatreya":

Mine and yours;

Mine, not yours.

Earth endures;

Stars abide- 
Shine down in the old sea;

Old are the shores;

But where are old men?

I who have seen much,

Such have I never seen.

Here is the land,

Shaggy with wood,

With its old valley,

Mound and flood.

But the heritors?-

Fled like the flood's foam.

The lawyer and the laws,

And the kingdom,

Clean swept here from.

They called me theirs,

Who so controlled me;

Yet every one

Wished to stay, and is gone,

How am I theirs?

If they cannot hold me,

But I hold them?"

When I heard the Earth-song

I was no longer brave;

My avarice cooled

Like lust in the chill of the grave.

Emerson's divine love and his own experiences of spiritual illumination in his lyric oracles which symbolize the Hindu images are to a certain extent an outcome of his study of oriental books. He sings a divine song as "Celestial love." It has been quoted from Ralph Waldo Emerson - Poems:

Higher far,

Higher far into the pure realm

Over sun and star

Over the flickering Daemon film

Thou must mount for love

In a region where the wheel

On which all beings ride

Visibly revolves;

Where the starred eternal worm

Girds the world with bound and

term,

Where unlike things are like. (12)

His high reverence towards Hindus' sacred books was an outcome of his reading the available philosophic Indian literature, which could be perceived by means of his historical statement from his Letters: "I owed a magnificent day to the Bhagavad-Gita. It was the first of books; it was as if an empire spoke to us, nothing small or unworthy, but large, serene, consistent, the voice of an old intelligence which in another age and climate had pondered and thus disposed of the same questions that exercise us." (VI: 246; I: 322-3).

Emerson wrote a letter to German scholar and great Orientalist Max Mueller (1823 - 1900). The letter makes the truth about the Orient which fascinates him; there is an expression of love for Oriental study. He writes:

All my interest is in Marsh's Мanu, then Wilkins' "Bhagavat Geeta," Burnouf's "Bhagavat Purana" and Wilson's "Vishnu Purana," yes, and few other translations. I remember I owed my first taste for this fruit to Cousin's sketch, in his first lecture, of the dialogue between Krishna and Arjuna and I still prize the first chapters of the Bhagavat as wonderful. (Journals, Vol $.10-14)$

It was his eagerness to possess the valuable Eastern scriptures that by 1856, Emerson had read the "Kathopanisad," his ideas were increasingly reflecting Indian influence, and his pages were filled with the ancient religious wisdom. The influx of new ideas of the poem seems to be under influence after reading Vishnu PuranaKatha and Upanishad, the concluding structure offers earnest appeal to the United States of America which was facing the state of agitation and tumultuous environment. And here are a few verses from the Bhagavad-Gita (Chapter 2- Original text: Bhagavad Gita: ) which represent the same concept of the immortality of human Soul:

He who shall say, Lo! I have slain a man!

He who shall think, Lo! I am slain!" those both

Know naught ! Life cannot slay. Life is not slain!

Never the spirit was born; the spirit shall cease

To be never;

Never was time it was not; End and beginning

Are dreams!

Birthless and deathless and changeless remaineth

The spirit for ever; 

dead though

Death hath not touched it at all,

The house of it seem! (10)

Wheel is a frequently used as a symbol in Brahminical literature. It had a remarkable influence, causing artistic creation, and especially in Buddhistic Religious books. There are some passages in the Rig Veda, having examples of wheel symbols. It was also a symbol of the continuous birth or rebirth of individual souls. All were explored by him in his spiritual writings. The Hindu theories of Transmigration, and Fatalism (according to the Hindu theory, Transmigration is the part of religious creed when soul goes into another body; Fate is nothing but results of deeds committed in a prior state of existence as Karma) had great influence on Emerson. His dogma of Fate has a relationship to the Oriental thought and has influenced his fatalistic writings. The Islamic fatalism (Power believed to predetermine all events from eternity: the Almighty determines the course of human life) is a vast branch of Islamic theology and an integral part of the Faith in Oneness of God.

The genesis of Orientalism in Emerson can be investigated through his letter to his aunt, Mary Moody, which was written after he came back to Boston on June 10, 1822. He was in a state of mental uneasiness and was tired of the kind of life which he was leading in America. It is worth referring to a few lines from his letter, showing his interest in Indian myths and his negative opinion regarding European barren life. He looks upon European life with disapproval.

"I am curious to read your Hindu mythologies. One is apt to lament over indolence and ignorance, when we read some of those sanguine student of the Eastern antiquities, who seem to think that all the books of knowledge, and all the wisdom of the Europe twice told, lie hidden in the treasures of the Brahmins \& the volumes of Zoroaster." (Letters 1, 116)

Emerson wrote a poem "Indian Superstition" at the age of 17. It was presented for Harvard college exhibition. It was the time when fascination with the Far East had started culminating in the highest point. This exhibition was embellished with various pieces of Oriental writings such as "On the Indian Astronomy," "The Institutions of the East Indians." These are some of the examples ofOriental writings which changed not only common people's passive opinion regarding the East but also added to the curiosity of the poets, writers, readers, students and Humanists towards Oriental readings.

\section{REFERENCES}

[1] Carpenter, Fredrick. Emerson and Asia: Cambridge University Press, 1930. Print.

[2] David, Robinson. Emerson and the Conduct of Life: Pragmatism and Ethical New York: Cambridge University Press. 1993. Print.

[3] Ekhtiar, Mansour. Emerson and Persia Mysticism: Iran: Tehran University, 1976. Print.

[4] Emerson, Ralph Waldo. The Heart of Emerson's Journals: ed. Bliss Perry. Boston. Houghton Mifflin, 1914. Web.

[5] Emerson, Ralph Waldo. The Complete Works of Ralph Waldo Emerson: ed. Edward Emerson. Boston. Houghton Mifflin, 1914. Print.

[6] Goldberg, Philip. American Veda: from Emerson and Beatles to Yoga and Meditation: Crown publishing Group, 2010. NYK. Print.

[7] Hawthorn, Jeremy. Studying the Novel. London: Hodder, 2005. Print.

[8] Kennedy, Sloane William. Clews to Emerson's Mystic Verse. USA: OUP, 1903. Print.

[9] Khayyam, Omar. Rubaiyat-i-Hakim Omar Khayyam. Ouseley Manuscript. The

[10] Bodleian Library, Oxford, 1987. Print.

[11] Kuhn, Bond Alvin. Modern Revival of Ancient Wisdom: New York, 1930. Print.

[12] Leask, Nigel. British Romantic Writers and the East: Anxieties of Empire. Cambridge: Cambridge UP, 1992. Print.

[13] Schwab, Raymond. The Oriental Renaissance. Trans. Gene Patterson-Black and Victor 